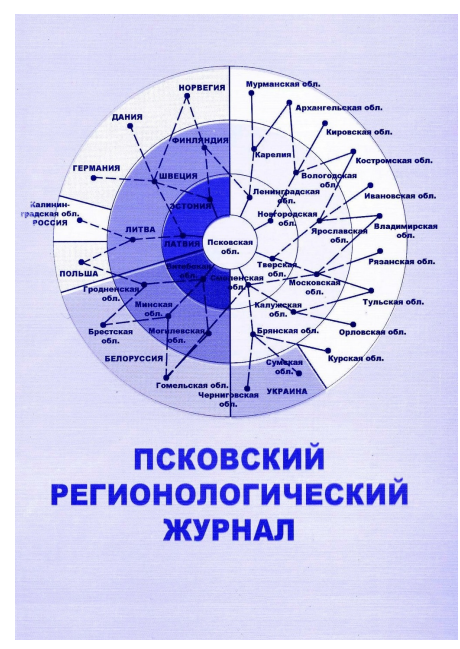

Псковский регионологический журнал. 2013-2023

ISSN 2219--7931

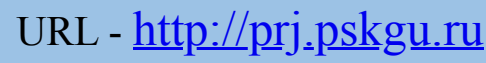

Все права защищены

Выпуск 2 (46) Том . 2021

\title{
Spatial aspects of gender inequality of the european union countries (on the example of the Republic of Finland)
}

\section{Дмитриева Анастасия Анатольевна}

Herzen Russian State Pedagogical University

Russian Federation, St.Petersburg

Дегусарова Валентина Сергеевна

Herzen Russian State Pedagogical University

Russian Federation, St.Petersburg

Трищ Надежда

Herzen Russian State Pedagogical University

Russian Federation, St.Petersburg

\section{Васильева Ольга}

Herzen Russian State Pedagogical University

Russian Federation, St.Petersburg

\section{Аннотация}

The article examines the problems of maintaining gender inequality in the EU countries, which, despite the successful experience of individual countries, is decreasing too slowly. Modern democracies recognize the equality of men and women as basic social values, but today the gender equality policy is most successful in the Nordic countries, in particular in Finland. To confirm this, the key historical stages of changes in the legal status and position of women in the EU countries are considered, a review of the main legislative documents regulating the rights of men and women is carried out, and a spatial interpretation of intercountry differences is presented. The study used a comparative characteristic of one of the main integral indicators characterizing the unequal attitude of men and women in certain spheres of life - the index of gender inequality in the EU countries, including the dynamics of the world ranking of each country. 
On the example of Finland, the process of feminization of society is examined in detail, the main indicators that determine the inequality of men and women in social and political spheres (the ratio of men and women in the national parliament; the wage gap; educational structure of men and women) are analyzed.

Ключевые слова: gender inequality, geographic interpretation, index of gender inequality, Europe, Republic of Finland

Дата публикации: 28.06.2021

\section{Ссылка для цитирования:}

Васильева О. , Дегусарова В. С. , Дмитриева А. А., Трищ Н. Spatial aspects of gender inequality of the european union countries (on the example of the Republic of Finland) // Псковский регионологический журнал. - 2021. - Выпуск 2 (46) С. 46-57 . URL: https://prj.pskgu.ru/s221979310014328-3-1/. DOI: 10.37490/S221979310014328-3

1 Introduction. Over time, attention to the issue of equality between men and women has grown. The unequal position of men and women in society does not allow full disclosure of human potential. To study this issue, the UN introduced the Gender Inequality Index, which examines inequality in relation to women in the most important spheres of society, such as medicine, education, labor and political activity.

2 European countries are in many respects leaders in overcoming gender inequality. Democratic development of the second half of the twentieth century. inseparable from significant changes in the gender consciousness and gender relations of their citizens. Already in the 19th century. European women began to defend their rights, largely due to the long path, European countries have achieved such success in this matter.

3 The purpose of the study is to study the spatial aspects of gender inequality in the countries of the European Union, including the example of the Republic of Finland.

4 The scientific novelty of the research is manifested in the comparative analysis of the conditions and results of achieving national gender equality in the subject framework of social geography using its research tools.

$5 \quad$ Research results. In such UN documents as the Convention on the Elimination of All Forms of Discrimination against Women (1979) [2], the Beijing Platform for Action and the Beijing Declaration (1995), fundamental approaches to the problem of gender equality are formulated. In addition, in 2000, the Millennium Declaration was formulated and adopted, one of the goals of which is to expand the opportunities and rights of women around the world, as well as achieve gender equality in all spheres of life. These documents became the foundation in the process of affirming the principle of equality of women and men and the basis for the formation of a single global gender policy. Since the 1970s. special laws on equal rights and opportunities have been adopted in Sweden, Denmark, Norway, Finland, France, Germany and other countries $[7 ; 9]$. 
The Nordic countries (Norway, Sweden, Finland, Denmark, Iceland) have undoubtedly achieved the greatest results in the implementation of gender state policy, the purpose of which is to create equal conditions for the self-realization of an individual regardless of gender. These states are recognized leaders in the field of ensuring the rights of women, and national mechanisms for gender equality are successfully implemented here. However, the concepts of gender equality in each of the countries of the Northern European region differ in matters of ideological content $[6 ; 8]$.

In Finland, the model of gender equality is based on the idea of gender neutrality, the "similarity" of men and women. In this state, a whole complex of statelegal mechanisms has been created and is actually functioning, aimed at ensuring de facto equality of the sexes. Firstly, the Republic of Finland has a special Gender Equality Law, adopted in 1986 and amended by the 1995 law, according to which quotas were introduced for the representation of each gender among members of state and municipal committees, commissions, working groups and others. bodies engaged in the development and adoption of decisions in appointed (not elected bodies) [5]. It is this normative legal act that clearly defines the prohibition of discrimination on the basis of sex. Secondly, in 2000 a special state body was created under the Ministry of Social Security and Health, whose tasks are to develop and prepare the necessary amendments to the Law on Equality. Thirdly, the judiciary is actively involved in the development of equality, for example, control and protection of equality between men and women is one of the main duties of the President of the Court of Justice of Finland. At the same time, this judicial institution receives a negligible number of applications and statements about discriminatory crimes, since the Finnish population is more willing to turn to the Ombudsman under the Government on these issues [8]. Fourth, the quota system develops Finnish mechanisms for gender equality policy. So, in accordance with the Law on Equality, state committees, commissions, advisory councils and other bodies with relevant competencies, as well as city government bodies, with the exception of municipal councils, must have at least $40 \%$ of representatives of the same sex (men or women), if certain reasons do not force a different gender configuration [4].

8 Either way, the causes of gender equality or gender inequality are rooted in historical, economic, cultural, political and legal traditions.

9 Gender Inequality Index. An indicator reflecting the inequality of men and women in various spheres of society is the Gender Inequality Index. This indicator is calculated by the specialists of the United Nations Development Program (UNDP) and published in the framework of human development reports, as one of the components that make up this indicator. The Gender Inequality Index looks at three main areas: 1) protection of reproductive health; 2) civil rights and opportunities; 3) opportunities in the labor market.

10 The method for calculating the indicator was developed by the American scientist S. Seth. He proposed to compute the index using a relationship-sensitive measure of inequality, which implies that the index is based on the overall average of the total means of various orders. At the initial stage, aggregation is carried out according to measurements within each gender group using geometric means, then the indices for women and men are aggregated according to the harmonic mean ${ }^{1}$. The Gender Inequality Index measures the level of a state's achievement of equality. When 
calculating the index, such components are considered: 1) protection of reproductive health, measured by the following indicators: - the maternal mortality rate (the number of deaths of women during pregnancy or childbirth per 100 thousand children born alive); - the birth rate among adolescents (the number of births among women aged 1519 in terms of 1,000 women of this age); 2) civic empowerment measured by two indicators: - the proportion of seats in the national parliament held by women, expressed as a percentage of the total number of seats; - the proportion of adult women and men (aged 25 and over) with at least secondary education; 3) opportunities in the labor market (the level of participation in the labor force of women and men aged 15 and over) [13].

11 The index shows the loss to human development due to inequality between men and women in the areas covered. The gender inequality index is measured in the range from 0 to 1 . Higher values of the index indicate a higher level of inequality in society, and, as a consequence, higher losses for human development [13]. In 2018, UNDP conducted research in 162 countries, so far none of them has a gender inequality index of 0. Switzerland is the leader in achieving equality, in which in 2018 the gender inequality index was 0.037 . Further, the rating includes the following countries (in ascending order of the indicator): Denmark (0.040), Sweden (0.040), the Netherlands (0.041), Norway (0.044), Belgium (0.045), Finland (0.050), France (0.051), Iceland ( 0.057). In South Korea, the last ten countries, the indicator was 0.058 . The highest value of the index was recorded in Yemen, where the gender inequality index was 0.834, which is 22 times higher than the minimum level of inequality calculated in Switzerland. Of the 162 responding countries, the top twenty leading countries that are closest to achieving gender equality include 14 out of 28 EU countries [6].

12 As a result of the study and collection of UNDP statistics, data were obtained that are reflected in Pictures 1 and 2.

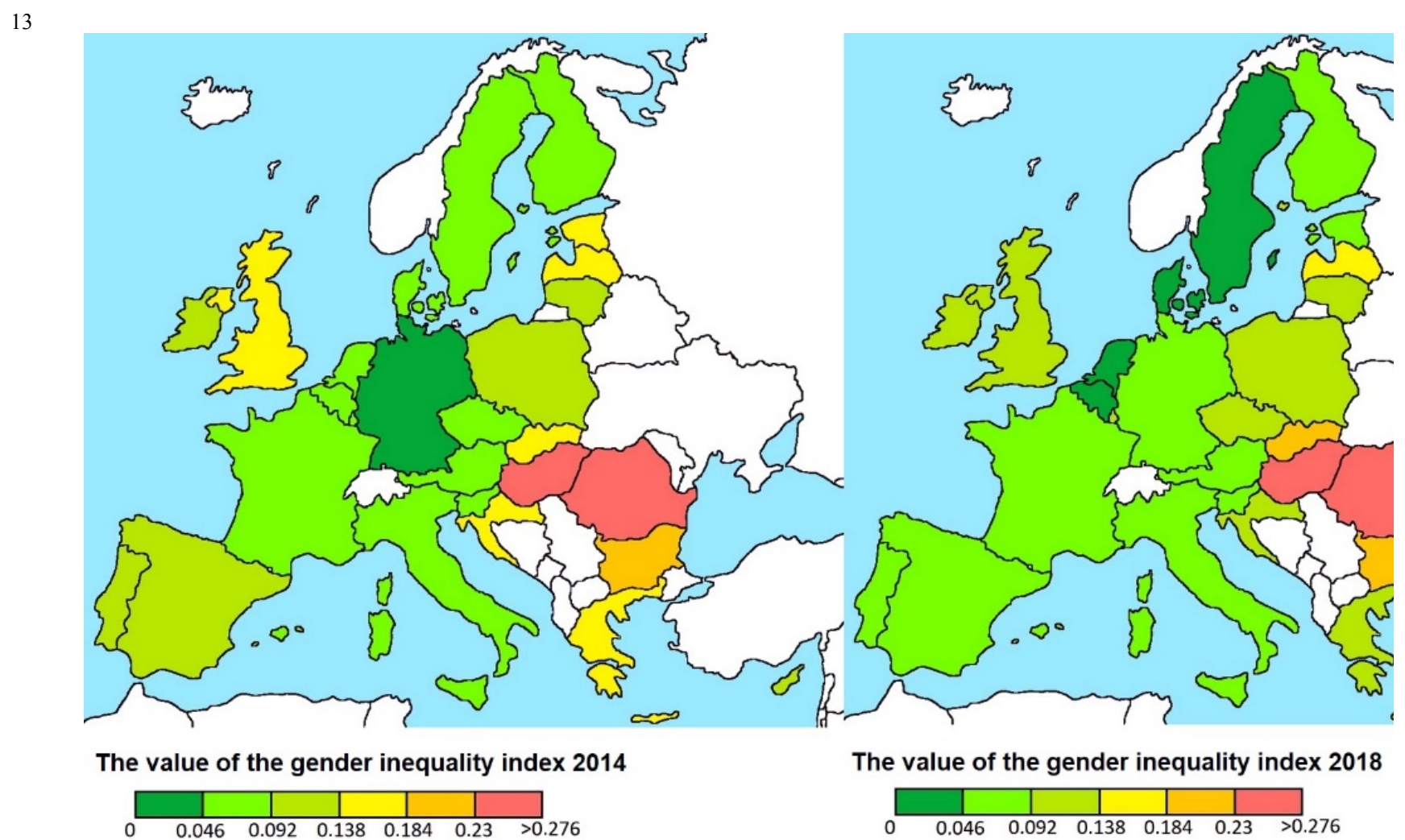

Pic. 1. Gender Inequality Index for European Union Countries (2014 and 2018)2. 


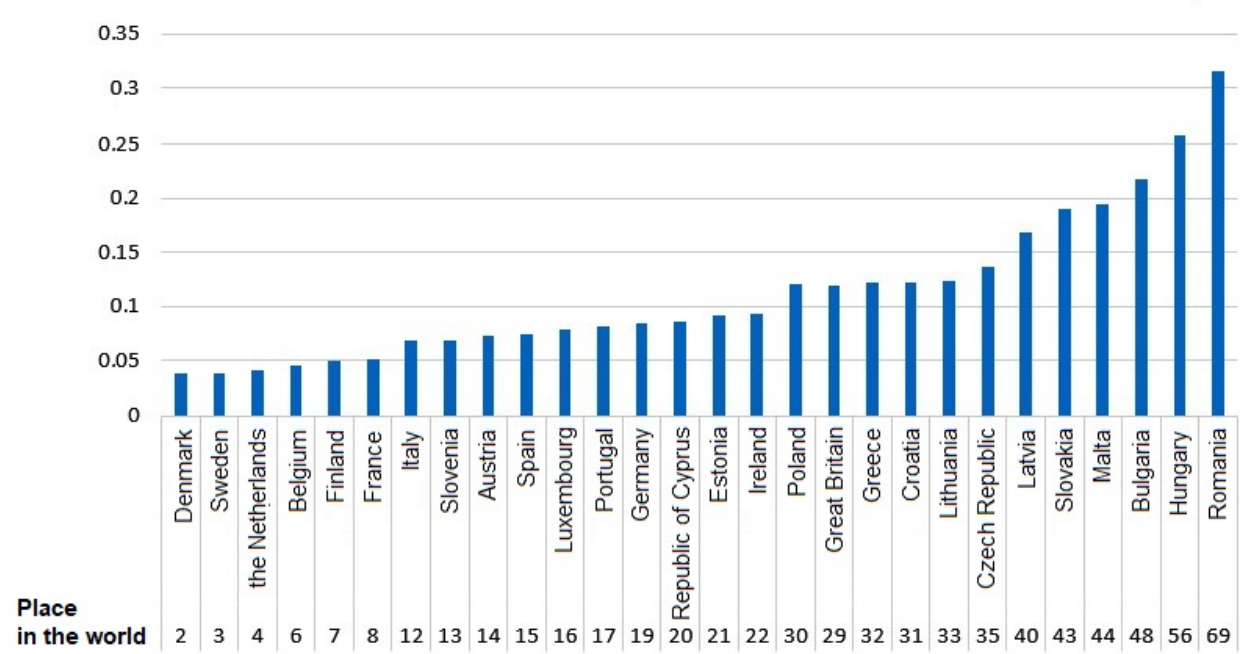

Pic. 2. EU Gender Inequality Index (2018)

15 The approaches of the European Union in the fight against discrimination, as well as a set of measures aimed at eliminating both gender inequality and any other inequality in society, and implemented in the EU countries, turned out to be effective, successful and effective. This is confirmed by the positive dynamics of national indices of gender inequality, in general, in the period from 2014 to 2018. the positive indicator was 0.31 points. Based on preliminary estimates, we can expect that in 2019 the trend of the positive dynamics of the index will continue. At the same time, an increase in the gender inequality index in such countries should be noted: Germany, Austria and Hungary. These are the countries to which refugees from Syria aspired, which became one of the factors of increasing gender inequality. Despite this, the European Union remains the world leader in overcoming gender inequality, which is confirmed by the adopted strategy for the development of equality [12].

16 The development of equal opportunities policies has enabled women in these countries to take a place in the labor market on an equal footing with men. While there are certain differences in wages for both sexes, it should be noted that this difference across the region is insignificant. The result of the implementation of mechanisms for ensuring equality between the sexes, on the one hand, is a network of institutions and positions, on the other, a system of anti-discrimination legislation.

17 Undoubtedly, every country in the world has its own development goals and not all countries have one of the primary tasks to overcome the gender gap, but still most of them are moving in this direction, albeit at different speeds and using different principles. Measures taken by the European Union to narrow the gender gap can be replicated by other countries to succeed in tackling discrimination issues.

18 Characteristics of gender inequality in Finland. Today Finland can be seen as a country that successfully overcomes gender inequality in all spheres of society. However, this process has been going on for many decades and remains unfinished until now.

19 It is worth starting with the fact that Finland was not an independent state for almost 1000 years - from 1104 to 1809. the country belonged to Sweden, from 1809 to 1917. - The Russian Empire, in this regard, the policy was dictated by other states. During the heyday of the suffrage movement, women in Finland actively acted and defended their interests, so they received the right to primary education. In the city of 
Vyborg in 1768, the first school was opened, which involved the education of girls, soon such schools were opened throughout the country. The Russian Empire also made its own adjustments to the status of women in Finland: - since 1864 inheritance law was received; - since 1901 the right to higher education (since 1871 the right to study in higher educational institutions); - since 1889 the right to personal income; - since 1906 electoral right.

$20 \quad$ Finland became the first country in Europe and the third in the world where women received voting rights. In the first elections in 1907, 19 women entered parliament, receiving $10 \%$ of the seats.

21 Thus, in 1906, a democratic electoral institution had already emerged in Finland, in which women became full-fledged participants in the political life of society. Further, since 1917, women had the right to municipal elections, since 1926 - the right to hold public office, since 1930 - equal rights in marriage.

22 Miina Sillanpää became the first female minister in 1926, after women received the right to hold public office. Her contribution to the development of the social system in Finland made it possible to view feminism as an opportunity for society to fully reveal its human potential for its development.

23 The process of women's involvement in the political life of Finnish society was slow. And at the same time, this figure was the highest in Northern Europe for a long time, up to the mid-90s. (pic. 3).

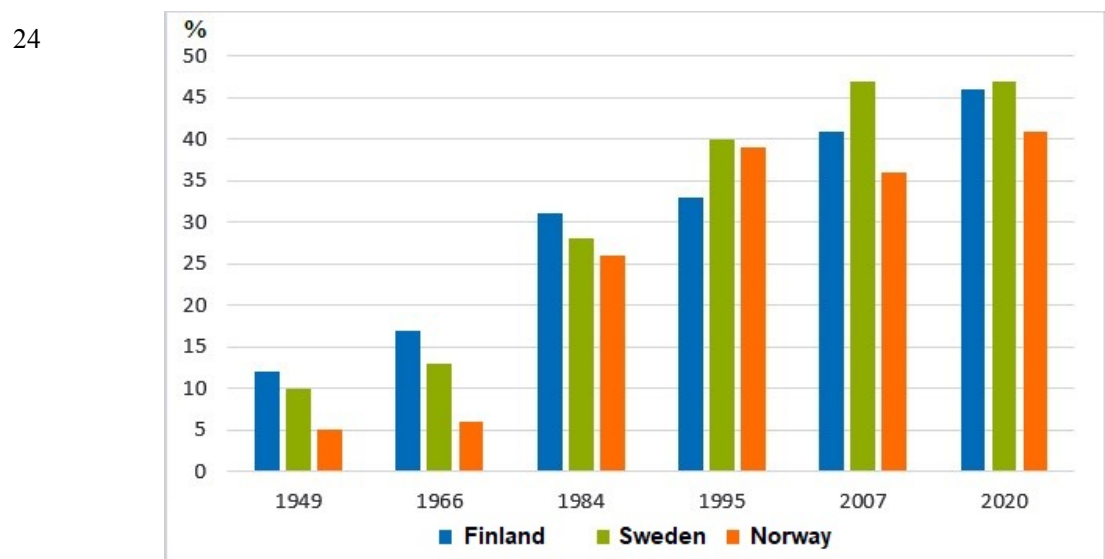

Pic. 3. Share of women in the national parliaments of Finland, Sweden and Norway (1949-2020),\%4

25 The involvement of women in the political life of the country proceeded at a relatively low rate, however, the adopted system of quotas significantly influenced the gender composition of the state and municipal administration, the formation of political institutions of equality (the Government Ombudsman Institute, the Council for Gender Equality, etc.). The results of the campaign campaigns of these bodies can be expressed in numbers: in 1984 women accounted for $25 \%$ of municipal councils, in $1988-27 \%$, in $1992-30 \%$, in $1996-31 \%$ [11]. As of January 1, 2020, 92 of the 200 seats in the Finnish Parliament are held by women ${ }^{5}$, while many countries have not reached the gender indicators of Finland in the 1940s.

26 In 2000 Tarja Halonen became the President of the country. Until that moment, only in four countries of the world a woman became president. T. Halonen had high ratings among citizens, she headed the state for two terms, until 2012. Women in Finland 
held high political posts and before the presidency of Tarja Halonen, for example, in 1994, Riitta Maria Uosukainen became the speaker of the Finnish parliament for the first time, in 2003 - Anneli Tuulikki Jaatteenmäki headed the government. Sanna Marin has been the Prime Minister of Finland since 2019. Currently, after the elections in June 2019, the Finnish cabinet of ministers consists of 19 people, of whom 12 are women and 7 are men, but a similar ratio was observed before.

27 Women in Finland showed their activity not only in the political life of the country, they acted in a similar way in all spheres of society, creating various organizations. For example, one of the first organizations was the "Women's Union", which arose in 1884, and later the "Union of Women's Rights Organizations" separated from it. All such organizations have one goal - to support women, protect and expand their rights and freedoms, create social benefits, etc.

28 Among other measures, it is worth noting the law on equal pay for equal work. Reportedly, the wage gap between men and women is gradually narrowing every year (Picture 4). According to the Organization for Economic Co-operation and Development (Women in Work Index, 2019), Finland is ranked 9th in the global ranking of countries where women are successful in employment ${ }^{6}$.

29

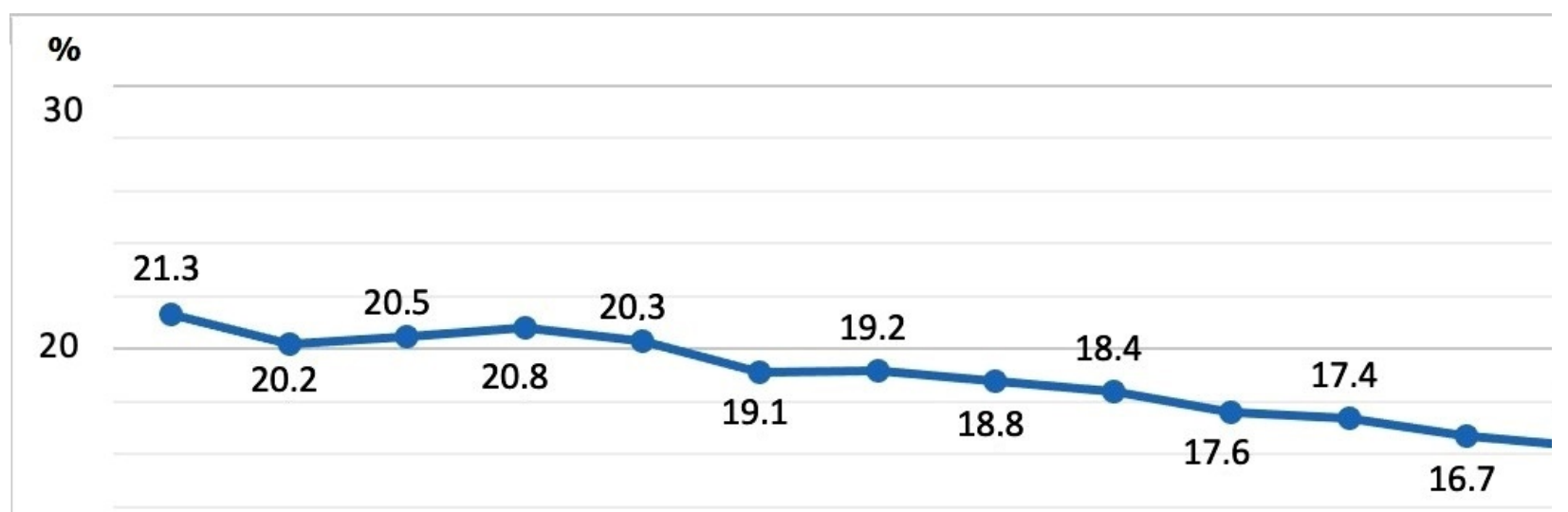

10

$\begin{array}{llllllllllll}2006 & 2007 & 2008 & 2009 & 2010 & 2011 & 2012 & 2013 & 2014 & 2015 & 2016 & 2017\end{array}$ :

Pic. 4. The gender pay gap, Finland (2006-2018),\% $\%^{7}$

30 In Finland, there has been a steady increase in the proportion of people with higher education, with the proportion of women with higher education exceeding the proportion of men by an average of $10 \%$ (Pic. 5). 


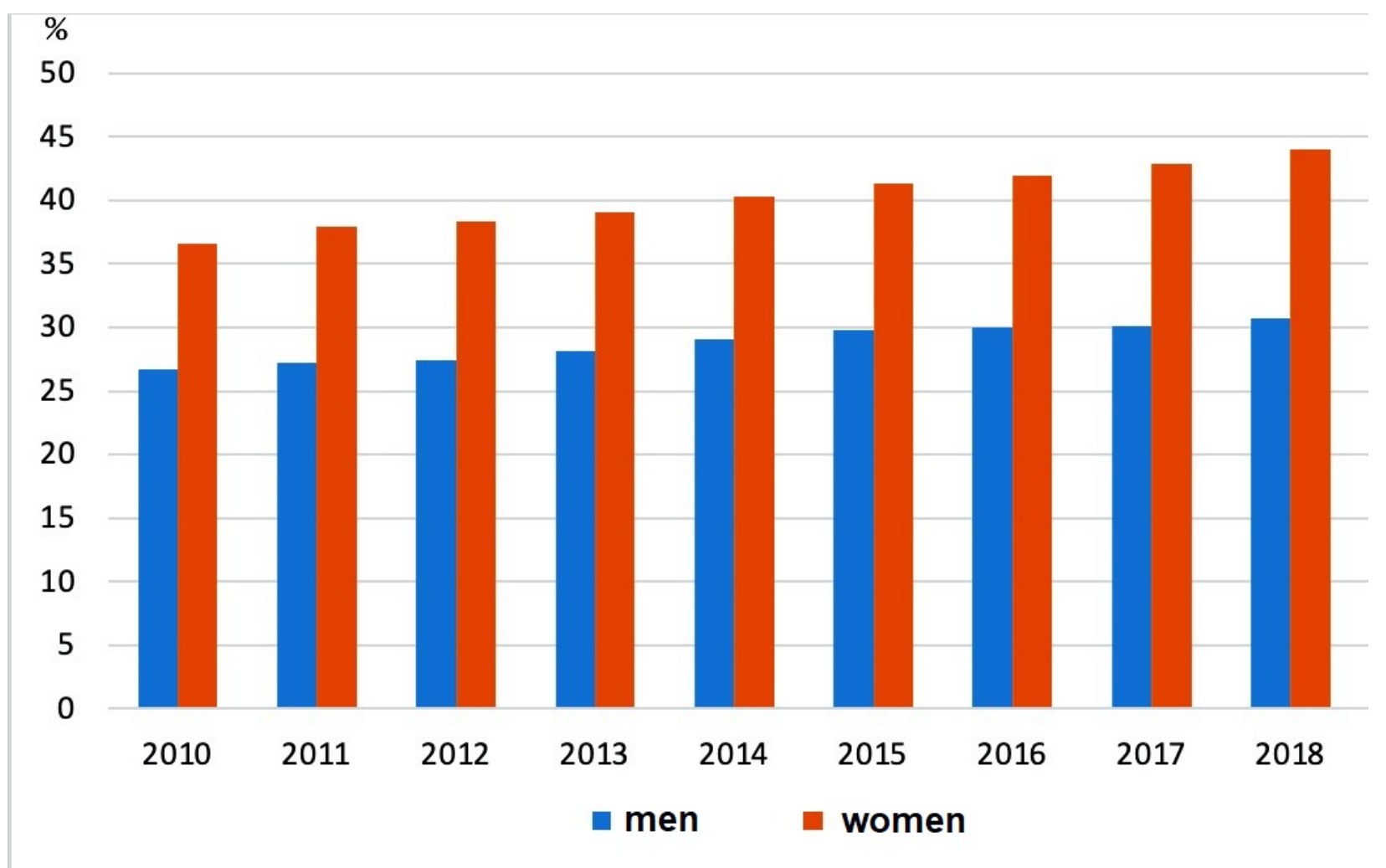

Pic. 5. Proportion of men and women aged 15-64 with tertiary education (Finland, $2010-2019)^{8}$

32 Referring to UNDP data for the period from 2014 to 2018. (Pic. 6), it is possible to trace the tendency for the reduction of gender inequality in Finland in recent years. This undoubtedly testifies to the high development of the country's social level.

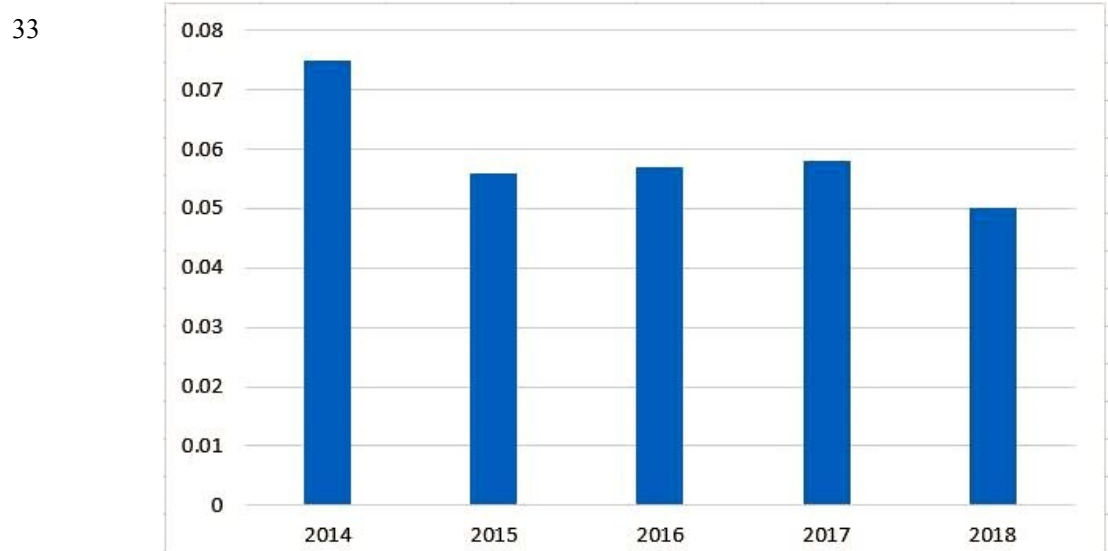

Pic. 6. Gender Inequality Index, 2014-2018 in Finland ${ }^{9}$

34 Conclusions. Summing up, it is necessary to note the length of the process of achieving gender equality, as well as the fact that this process proceeds in its own way in different countries. The countries of the European Union can be called leaders in overcoming gender inequality. However, among the EU countries there are significant differences in addressing the issue of gender equality. With the introduction of the UNDP Gender Inequality Index, it became possible to regularly measure gender differences and monitor the effectiveness of the implemented mechanisms for ensuring gender equality.

35 The gender inequality index is calculated based on the analysis of various indicators, the main of which are: reproductive health protection, access to education and its availability, equal opportunities in the political sphere and in the labor market. 
The analysis of the index allows us to conclude that the gender gap in the countries of the European Union continues to decrease, as evidenced by the positive dynamics of the index in the period from 2014 to 2018.

36 However, internal differences between the countries of the European Union are still significant, for example, for the countries of Eastern Europe - Romania, Hungary and Bulgaria - there is a significant gap in achieving gender equality, which is explained by the complex ethnic structure of the population, their historical past, as well as the national policies of states.

37 The specifics of the migration situation, as, for example, in Germany, can also participate in shaping the spatial aspects of gender inequality. Here society, on the one hand, has a fairly high level of gender equality. On the other hand, large diasporas living in the country and not sharing the values of European society have an impact on the overall perception of the level of gender equality in the country, since migrant women are poorly involved in the labor and other spheres of society. The highest rates of gender equality are found in the Nordic countries, and they have a long and relatively similar path to bridging the gender gap. The Scandinavian model of equality is characterized by developed mechanisms of institutionalization, a system of social support, sufficient funding, wide coverage of various social groups of the population, and job security [10]. Finland is a country where women have defended their rights for decades and have done so with great success. Feminism merged into life smoothly and without conflict, and most importantly, it successfully entrenched itself in the mentality of Finnish citizens. This is manifested even in the peculiarities of the language, since in the Finnish language no distinction is made between the pronouns "he" and "she", which are familiar for many countries - in both cases it is "hän". In Finland, women are supported at the state level, there are existing mechanisms that are introduced into society and bring a positive result, various social movements have been created that support women, defend their rights and protect their interests, there are adaptation courses for migrants aimed at acquaintance with Finnish values and a policy of equality.

38 Today Finland is among the top ten countries in the world in terms of the main indicator characterizing the inequality of men and women in various spheres of society the gender inequality index. The share of women with higher education exceeds the share of men, and the pay gap between men and women is decreasing every year. All this confirms that Finland has achieved a high level of gender equality. Of course, not all countries in the world put gender equality as a priority for the state. However, the experience of the Republic of Finland in ensuring gender equality is being adopted by other EU countries, thereby reducing the existing gender gap.

Примечания:

1. Women in Work Index 2019. [Electronic resource]: URL: $\geq>>>$ (date of application 07.02.2021). 


\section{Библиография:}

1. Voronina O. A. (2004), Feminism and gender equality, Moscow, 2004. 320 p. (In Russ.).

2. Convention on the Elimination of All Forms of Discrimination against Women, New York, December 18, 1979 (1982), Vedomosti VS SSSR, June 23, no. 25, p. 464. (In Russ.).

3. Koroleva T. A. (2012), Ensuring equality of women in Finland: specifics of gender policy, Srednerusskij vestnik obshhestvenny`x nauk, no. 4 (1), pp. 134-138. (In Russ.).

4. Stepanova N. M. (1999), Experience of using gender quotas in Western Europe, Obshhestvenny`e nauki i sovremennost', no. 4, pp. 185-196. (In Russ.).

5. Stepanova N. M. (2003), Policy of gender equality in the Scandinavian countries, Gender reconstruction of political systems, SPb., ISPG-Aleteya, pp. 204-224. (In Russ.).

6. Shtyleva M. V. (2013), Formation of gender equality policy in the European Union (1950-2010), Zhurnal issledovanij social noj politiki, vol. 11, no. 1, pp. 87-102. (In Russ.).

7. Bacchi C. (2005), The Mageeq Project: Identifying Contesting Meanings of "Gender Equality", The Greek Review of Social Research, 117 B, pp. 221-234.

8. Equal Democracies? Gender and Politics in the Nordic Countries (1999), eds. by Bergqvist Ch. et al., Oslo, Scandinavian Univ. Press.

9. Hoskyns C. (1986), Women, European Law and Transnational Politics, International Journal of the Sociology of Law, no. 14, pp. 299-315.

10. Kvist J. (1990), Welfare reform in the Nordic Countries in the 1990s: using Fuzzyset theory to assess conformity to ideal types, Journal of European Policy, vol. 9, no. 3, p. 231.

11. Maninen M. (1999), The Status of Women in Finland. The First in the World to Gain Full Political Rights.

12. Union of Equality: Gender Equality Strategy 2020-2025, COM (2020), 152 final, European Commission, Brussels, $20 \mathrm{p}$. 


\title{
Spatial aspects of gender inequality of the european union countries (on the example of the Republic of Finland)
}

\author{
Anastasia Dmitrieva \\ Herzen Russian State Pedagogical University \\ Russian Federation, St.Petersburg \\ Valentina Degusarova \\ Herzen Russian State Pedagogical University \\ Russian Federation, St.Petersburg \\ Nadezhda Trishch \\ Herzen Russian State Pedagogical University \\ Russian Federation, St.Petersburg \\ Olga Vasilyeva \\ Herzen Russian State Pedagogical University \\ Russian Federation, St.Petersburg
}

Abstract

The article examines the problems of maintaining gender inequality in the EU countries, which, despite the successful experience of individual countries, is decreasing too slowly. Modern democracies recognize the equality of men and women as basic social values, but today the gender equality policy is most successful in the Nordic countries, in particular in Finland. To confirm this, the key historical stages of changes in the legal status and position of women in the EU countries are considered, a review of the main legislative documents regulating the rights of men and women is carried out, and a spatial interpretation of intercountry differences is presented. The study used a comparative characteristic of one of the main integral indicators characterizing the unequal attitude of men and women in certain spheres of life - the index of gender inequality in the EU countries, including the dynamics of the world ranking of each country.

On the example of Finland, the process of feminization of society is examined in detail, the main indicators that determine the inequality of men and women in social and political spheres (the ratio of men and women in the national parliament; the wage gap; educational structure of men and women) are analyzed.

Keywords: gender inequality, geographic interpretation, index of gender inequality, Europe, Republic of Finland

Date of publication: 28.06 .2021

\section{Citation link:}

Degusarova V., Dmitrieva A., Trishch N., Vasilyeva O. Spatial aspects of gender inequality of the european union countries (on the example of the Republic of Finland) // 
Pskov Journal of Regional Studies. - 2021. - Issue 2 (46) C. 46-57 .

URL: https://prj.pskgu.ru/s221979310014328-3-1/. DOI: 10.37490/S2219793100143283

Код пользователя: 0; Дата выгрузки: 26.04.2023; URL - http://prj.pskgu.ru/s221979310014328-3-1/ Bce права защищены. 